Jahangirnagar University J. Biol. Sci. 8(1): 9-15, 2019 (June)

\title{
Characterization of rhizospheric and non rhizospheric bacteria from arsenic contaminated soil
}

\author{
Umma Mayda*, Nazifa Tasnim and Rasheda Yasmin Shilpi \\ Microbiology Laboratory, Department of Botany, Jahangirnagar University, Savar, \\ Dhaka-1342, Bangladesh
}

\begin{abstract}
The rhizosphere soil has a large and various number of microorganisms especially the bacteria. This experiment was conducted at the department of Botany, Jahangirnagar University, Savar, to investigate the rhizospheric and non-rhizospheric bacteria from arsenic contaminated soil. Pteris vittata was treated with different concentrations of arsenic ranges from 5000 to $10000 \mathrm{ppm}$ in the pot. The experimental result indicated that the negative correlation between arsenic concentration and rhizospheric soil bacteria. Highest number of bacteria $\left(8.6 \times 10^{8} \mathrm{cfu} / \mathrm{g}\right)$ were found in rhizospheric soil (control), while lowest numbers of bacteria $\left(4.0 \times 10^{7} \mathrm{cfu} / \mathrm{g}\right)$ were found in the non-rhizospheric soil with $10000 \mathrm{ppm}$ arsenic. Thirty bacteria were isolated from rhizospheric and non-rhizospheric soil samples. Out of thirty samples Bacillus and Pseudomonas were selected on the basis of morphological and biochemical nature. The present study concluded that the arsenic has an adverse effect on the growth of rhizospheric soil bacteria.
\end{abstract}

Key words: Characterization Pteris vittata, rhizospheric and non-rhizospheric soil

\section{INTRODUCTION}

Arsenic (As) is a metalloid element known as poison and its contamination is one of the promising public concerns in the whole world due to its toxic and carcinogenic nature (Singh et al., 2015). High concentration of arsenic has adverse effect on human health and environment (Hettick et al., 2015). In nature, arsenic can be found in four oxidation condition, among four oxidation states arsenate $[\mathrm{As}(\mathrm{V})]$ and arsenite $[\mathrm{As}(\mathrm{III})]$ are the abundance form in the environment. $\operatorname{As}(\mathrm{V})$ is known as phosphate analogue and is mixed with cellular processes, like oxidative phosphorylation and ATP synthesis, on the other hand, As (III) binds to the sulfhydryl groups and change the protein function (Oremland \& Stolz, 2005).

Widespread use of ground water for irrigation is a source of arsenic contamination in food chain (Huq et al., 2006) and the presence of arsenic in food chain (Duxburya et al., 2003; Das et al., 2004) affects human health directly or indirectly.

Arsenic also affects the soil microorganisms. The natural levels of soil arsenic range from 0.1 to $40 \mathrm{mg} / \mathrm{kg}$ in various countries (García-Sánchez et al., 2010). Anthropogenic sources like pesticide, insecticide, mining, coal combustion etc. generally exceed natural

\footnotetext{
* Corresponding author. Email: ummatumpa26@gmail.com
} 
level of arsenic in the environment (Mesa et al., 2017). More than 10,000 arsenic contaminated sites have been reported in Australia (Smith et al., 2008).

On the other hand, microbial interaction plays a major role in the plant growth (Lampis et al., 2015). Bacterial mechanisms increase the plant growth by using bacterial metabolites, like indole-3-acetic acid (IAA), different kinds of acid production, soil acidification, solubilization of phosphates and methylation (Lebeau et al., 2008; Ma et al., 2011). Bacteria colonize the plant tissue and promote plant growth through mechanisms such as IAA, phosphate solubilization and production or supplying necessary vitamins to plants for their growth and development (Ryan et al., 2008, Kuffner et al., 2010). Rhizosphere bacteria can act as biocontrol agents against pathogenic microorganisms and help is nitrogen fixation (Weyens et al., 2009). A sustainable technology for cleaning Ascontaminated soils is phytoremediation, which is defined as the use of plants to remove or reduce toxic concentrations of hazardous substances in the environment (Weis et al., 2004). Therefore, the current study was undertaken to investigate the effect of arsenic on rhizospheric and non-rhizospheric soil bacteria.

\section{MATERIALS AND METHODS}

Collection of samples: Rhizospheric and non-rhizospheric soil of Pteris vittata were collected from different pots containing and without containing arsenic. Then the soil was treated with 5000, 6000, 7000, 8000, 9000 and 10000 ppm arsenic. Sample was collected on the duration of 7,14 and $21^{\text {th }}$ days interval. Soil was collected very carefully and preserved at $4^{\circ} \mathrm{C}$.

Isolation of soil bacteria and bacterial load determination: Soil bacteria were isolated by using serial dilution methods (MacLowry et al., 1970). Nutrient agar medium was used for isolation of bacteria and microbial load determination. Microbial load was determined from the total number of discrete colonies counted after incubation. Isolated colonies were counted in colony formation unit as Number of cfu/volume plated dilution factor. The bacterial colonies were observed to study various characters viz. colour, form, elevation, margin, surface etc.

Purification and selection: Bacterial colonies were cultured on different selective and differential media such as: MacConkey, Bouillon agar, King's B media. Different biochemical tests (Casein test, Fermentation test, Indole test, Starch hydrolysis test, Catalase test, API 20E) were also performed for bacterial identification. Results of the morphological, cultural and biochemical tests of selected isolates were analyzed following Bergey's Manual of Systematic Bacteriology (Sneath et al., 1986).

\section{RESULTS AND DISCUSSION}

Isolated bacteria from arsenic contaminated soils were grown in nutrient agar with different concentrations of 5000,6000, 7000, 8000, 9000 and $10000 \mathrm{ppm}$ of arsenic. Highest number of bacteria $\left(8.6 \times 10^{8} \mathrm{cfu} / \mathrm{g}\right)$ grown in control soil and lowest number of 
bacteria $\left(8.0 \times 10^{7} \mathrm{cfu} / \mathrm{g}\right)$ were found in $10000 \mathrm{ppm}$ of rhizospheric soil with $10000 \mathrm{ppm}$ arsenic.

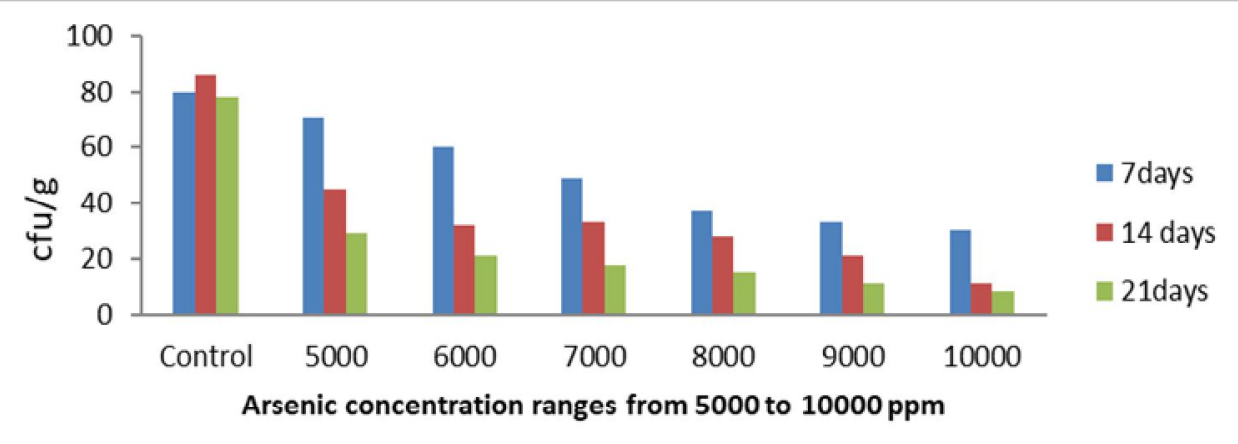

Fig. 1. Bacterial abundance in the rhizospheric soil of different concentration of arsenic (5000 to $10000 \mathrm{ppm})$ at different intervals

The results of graphical analysis of bacterial abundance in the non-rhizospheric soil of different concentration of arsenic are presented in Fig. 2. Highest number of bacteria $\left(8.2 \times 10^{7} \mathrm{cfu} / \mathrm{g}\right)$ was found in control and lowest $\left(4.0 \times 10^{7} \mathrm{cfu} / \mathrm{g}\right)$ were recorded from nonrhizospheic soil contain $10000 \mathrm{ppm}$ of arsenic. The results have clear indication that arsenic has negative relationship with bacterial abundance in the soil. Besides Fayiga et al. (2007) shows that arsenic has adverse effect on soil bacterial community and phytoremediation process helps to increase the bacterial community in the arsenic contaminated soil). Microorganisms are far more sensitive to heavy metal stress than soil animals or plants growing on the same soils. Evidence suggested that heavy metal have an extreme effect on soil microbial communities (Giller et al., 1998).

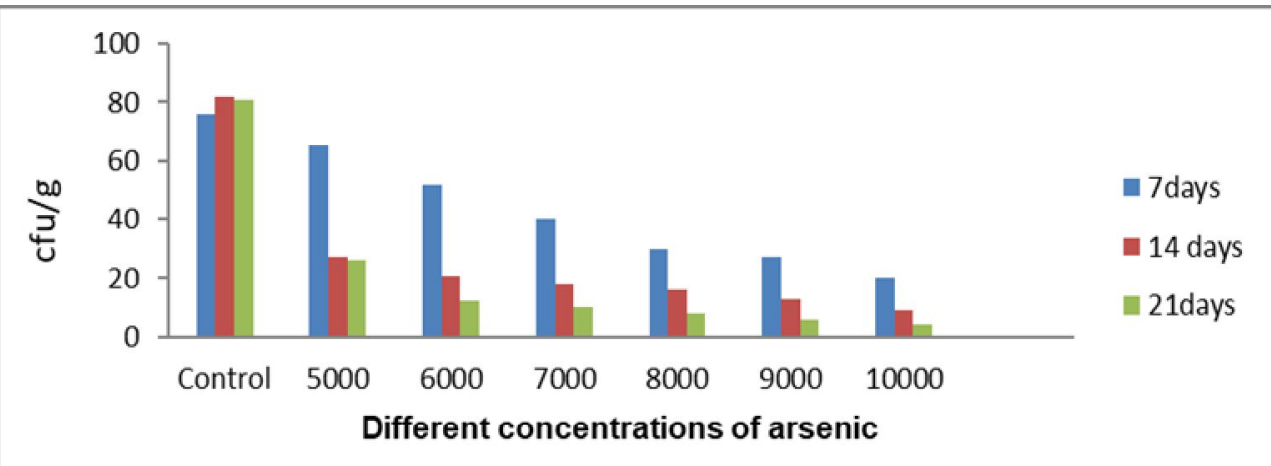

Fig. 2. Bacterial abundance in the non-rhizospheric soil of different concentration of arsenic at different intervals

Microorganisms and plants have developed several essential or adaptive mechanisms to mix with as enabling them to resist and metabolize it (Mesa et al., 2017). The rhizosphere 
soil is the source of high variety of microorganisms which play an important role in the enhancement of the plant growth. Interaction of plant and microbe helps to improve the plant growth (Prasad et al., 2014). Rhizosphere bacteria influence plant growth by changing the soil chemical properties and interact with plant roots and this influence can be beneficial, neutral, or deleterious (Russell 1977, Doi et al., 2007). Isolated bacteria from rhizosphere soils have showed the beneficial impact on plants by direct effect on nitrogen fixation (Han et al., 2005).

In the study thirty bacteria were isolated from rhizosphere and non-rhizosphere soil zone. The isolated was designed as $\mathrm{NZ}_{1}$ to $\mathrm{NZ}_{30}$. From the selective media NZ14, NZ15, NZ17, NZ27, NZ28 were identified by using morphological and biochemical test (Plate 1). Bacillus (Table 1) Pseudomonas was recognized during the experiment. Kloepper et al. (1989) isolated a large number of rhizospheric soil bacteria and identified among which the common species of Azospirillum, Azotobacter, Pseudomonas, Klebsiella, Enterobacter, Arthobacter, Burkholderia, Alcaligens, Bacillus and Serratia.
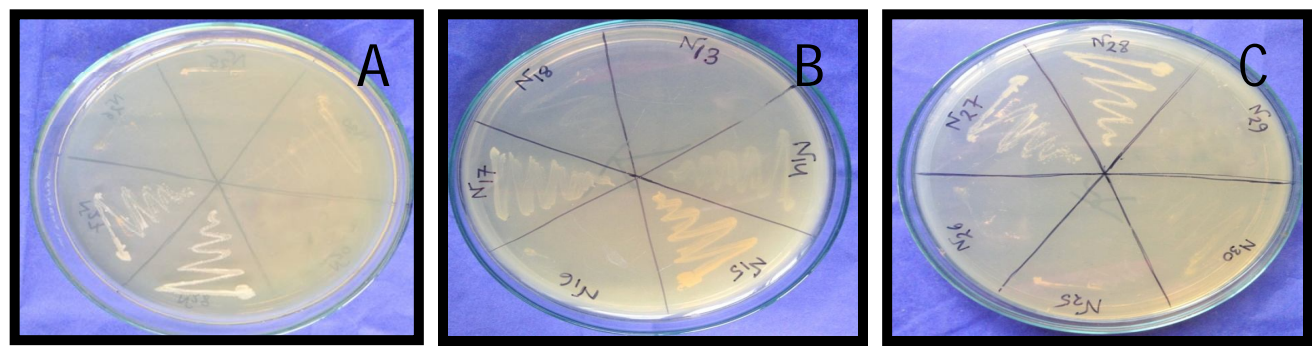

Plate 1. Photographic plates show the presence and absence of isolated bacteria on king's $B$ media. Here $A$ and $C$ show the off white and white color of $\mathrm{NZ}_{27}, N_{28}$. $B$ shows the off white color of $\mathrm{NZ}_{14}$, cream color of $\mathrm{NZ}_{17}$, orange color of $\mathrm{NZ}_{30}$

In the present study Bacillus and Pseudomonas were isolated through their typical colony characteristics on to the specific culture media. Bacillus sp. gave white colored colony on Bouillon agar and showed positive test in starch hydrolysis, endospore staining test (Plate 2). Pseudomonas sp. showed positive biochemical test in API $20 \mathrm{E}$ system during the experimental time (Plate 3 ). 


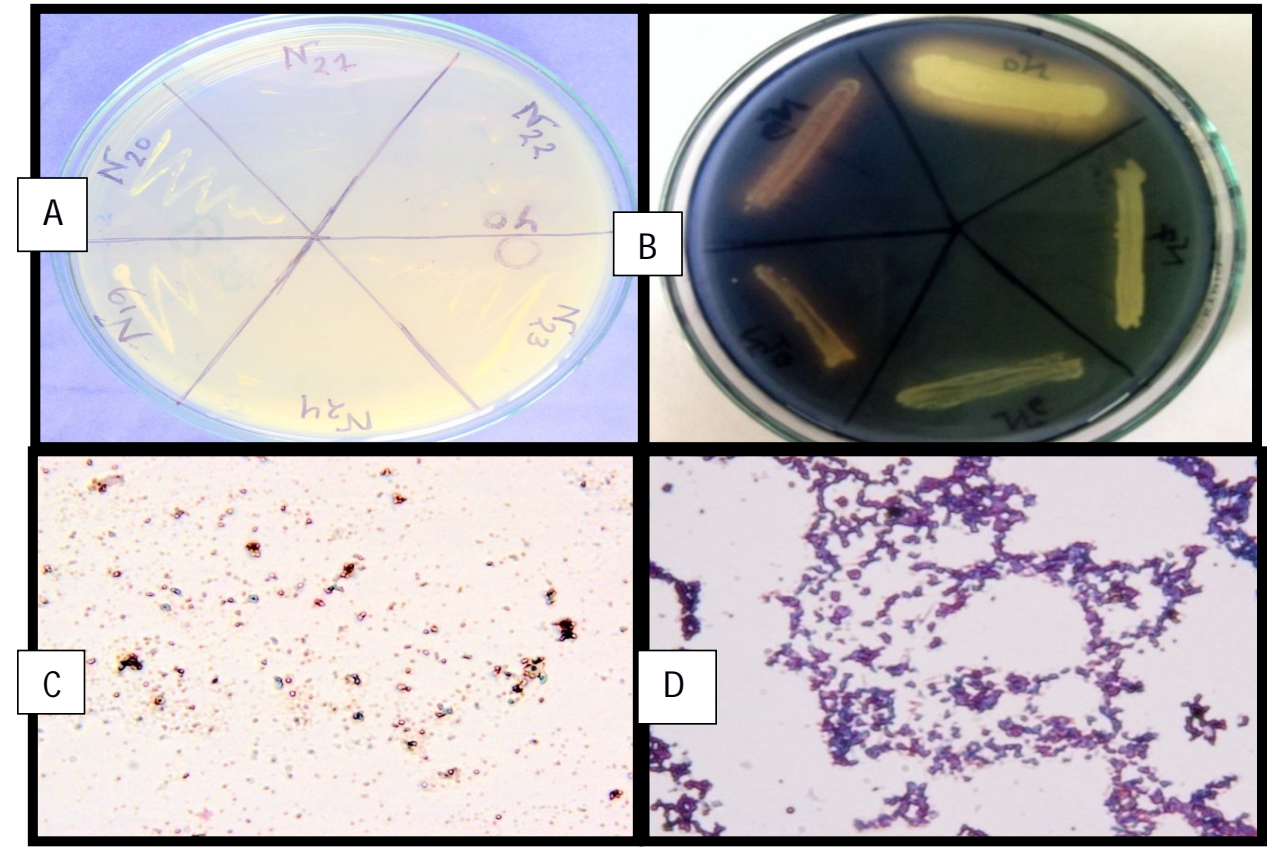

Plate 2. Bacterial colonies on Bouillon Agar media for Bacillus sp. (A), starch hydrolysis positive test (B), endospore staining positive test (C) and gram staining (D)

Table 1. Identification of Bacillus sp. (Sneath et al., 1986)

\begin{tabular}{c|c|c}
\hline Criteria & Result & Identification \\
\hline Shape & Rod shape & \\
Cell & Thick cell wall & Bacillus sp. \\
Gram staining & Gram positive & \\
Spore formation & Endospore & \\
Location of spore & Central & \\
Starch hydrolysis & Positive & \\
Growth at $50^{\circ} \mathrm{C}$ & Positive & \\
\hline
\end{tabular}

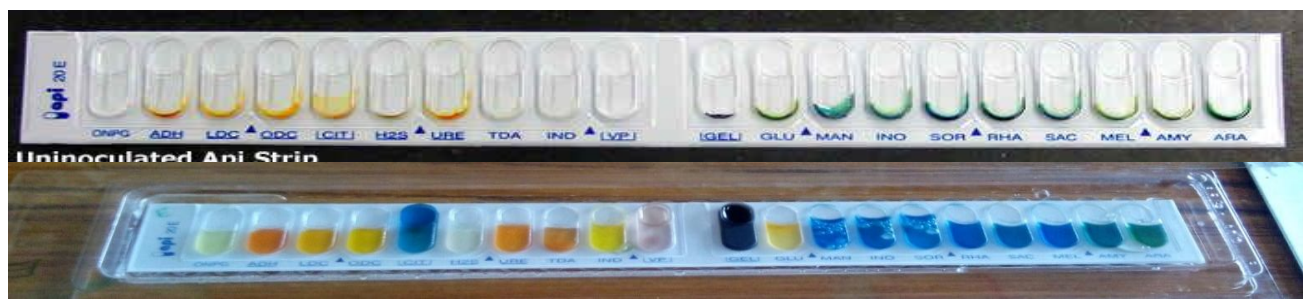

Plate 3. Identification of Pseudomonas isolated from rhizospheric soil arsenic using API 20 E system 
Soil bacteria that colonize plant roots and enhance plant growth are known as plant growth-promoting rhizobacteria (PGPR). PGPR are highly diverse and are used as bio control agents (Beneduzi et al., 2012). A rhizosphere bacterium helps to control the root knot nematode (Zhao et al., 2018). Rhizobacteria belonging to the genera Pseudomonas and Bacillus are well known for their antagonistic effects and has the ability to efficient biocontrol agents to improve cropping systems (Beneduzi et al., 2012). Huang (2016) described that many bacteria are tolerant to heavy metals and play important roles in the accumulation of heavy metals. Plant growth promoting rhizobacteria Pseudomonas aeruginosa have a heavy metal tolerance like cadmium which might be used as an ideal candidate for bioremediation and plant growth promotion against $\mathrm{Cd}$-induced stress (Huang et al., 2016). Therefore, the identified Bacillus and Pseudomonas, which are arsenic resistant bacteria and also beneficial rhizosphere bacteria for plant growth and development. These two bacteria have the potential bioremediation capacity which might be used to remove arsenic from soil.

\section{REFERENCES}

Beneduzi, A., Ambrosini, A. and Passaglia, L. M. 2012. Plant growth-promoting rhizobacteria (PGPR): their potential as antagonists and biocontrol agents, Genet. Mol. Biol. 35(4): 1044-1051.

Das, H. K., Mitra, A. K., Sengupta, P. K., Hossain, A., Islam, F. and Rabbani, G. H. 2004. Arsenic concentrations in rice, vegetables, and fish in Bangladesh: a preliminary study, Environ. Int. 30(3): 383-387.

Doi, T., Hagiwara, Y., Abe, J. and Morita, S. 2007. Analysis of rhizosphere bacteria of rice cultivated in Andosol lowland and upland fields using molecular biological methods, Plant root. 1: 66-74.

Duxburya, M., J., Mayerb, A. B., Laurena, J. G. and Hassanc, N. 2003. Food chain aspects of arsenic contamination in Bangladesh: Effects on quality and productivity of rice, J. Env. Sci. And Health. 38(1): 61-69.

Fayiga, A. O. and Ma, L. Q. Zhou. 2007. Effects of plant arsenic uptake and heavy metals on arsenic distribution in an arsenic-contaminated soil, Environ. Pollut. 147(3):737-742.

García-Sánchez, A., Alonso-Rojo, P. and Santos-Francés, F. 2010. Distribution and mobility of arsenic in soils of a mining area (Western Spain), Sci. Total Environ. 408(19): 4194-4201.

Giller, K. E., Witter, E. and Mcgrath, S. P. 1998. Toxicity of heavy metals to microorganisms and microbial processes in agricultural soils: a review. Soil Bio. Chem. 30(10-11): 13891414.

Han, J., Sun, L., Dong, X., Cai, Z., Sun, X., Yang, H., Wang, Y. and Song, W. 2005. Characterization of a novel plant growth-promoting bacteria strain Delftia tsuruhatensis HR4 both as a diazotroph and a potential biocontrol agent against various plant pathogens. Systematic Appl. Microbiol. 28(1), 66-76.

Harrigan, W. F. 1998. Laboratory methods in food microbiology. 3rd ed., Gulf Professional Publishing, USA, pp:120-175.

Hettick, B.E. and Cañas-Carrell, J.E., French, A.D. and Klein, D.M. 2015. Arsenic: a review of the element's toxicity, plant interactions, and potential methods of remediation, J. Agr. Food Chem. 63(32): 7097-7107.

Huq, I., S. M., Joardar, J. C., Parvin, S., Correll, R. and Naidu, R. 2006. Arsenic contamination in food-chain: Transfer of arsenic into food materials through groundwater irrigation, $J$. Health Popul. Nutr. 24(3): 305-316. 
Huang, J., Liu, Z., Li, S., Xu, B., Gong, Y., Yang, Y. and Sun, H. 2016. Isolation and engineering of plant growth promoting rhizobacteria Pseudomonas aeruginosa for enhanced cadmium bioremediation, J. Gen. Appl. Microbiol. 62(5): 258-265.

Kloepper, J. W., Lifshitz, R. and Zablotowicz, R. M. 1989. Free-living bacterial inoculate for enhancing crop productivity, Trends Biotechnol. 7(2): 39-44.

Kuffner, M., De Maria, S., Puschenreiter, M., Fallmann, K., Wieshammer, G., Gorfer, M., Strauss, J., Rivelli, A.R. and Sessitsch, A. 2010. Culturable bacteria from Zn- and Cdaccumulating Salix caprea with differential effects on plant growth and heavy metal availability, J. Appl. Microbiol. 108(4): 1471-1484.

Lampis, S., Santi, C., Ciurli, A., Andreolli, M. and Vallini, G. 2015. Promotion of arsenic phytoextraction efficiency in the fern Pteris vittata by the inoculation of As-resistant bacteria: a soil bioremediation perspective, Front. Plant Sci. 6: 80.

Lebeau, T., Braud, A. and Jézéquel, K. 2008. Performance of bio augmentation-assisted phytoextraction applied to metal contaminated soils: a review, Environ. Pollut. 153(3): 497-522.

Mac Lowry, J. D., Jaqua, M. J. and Selepak, S. T. 1970. Detailed methodology and implementation of a semi-automated serial dilution micro technique for antimicrobial susceptibility testing, Appl. Environ. Microbiol. 20(1): 46-53.

Ma, Y., Prasad, M.N.V., Rajkumar, M. and Freitas, H. 2011. Plant growth promoting rhizobacteria and endophytes accelerate phytoremediation of metalliferous soils, Biotechnol Adv. 29(2): 248-258.

Mesa, V., Navazas, A., González-Gil, R., González, A., Weyens, N., Lauga, B., Gallego, J.L.R., Sánchez, J.0. and Peláez, A.I. 2017. Use of endophytic and rhizosphere bacteria to improve phytoremediation of arsenic-contaminated industrial soils by autochthonous Betula celtiberica, Appl Environ Microbiol. 83(34): 11- 16.

Oremland, R.S. and Stolz, J.F. 2005. Arsenic, microbes and contaminated aquifers, Trends Microbiol., 13(2): 45-49.

Prasad, M. P. 2014. Isolation and screening of Rice Rhizosphere Soil microorganisms for the production of IAA, Int. J. Curr. Microbiol. App. Sci. 3(9): 993-998.

Russell, R. S. 1977. Plant root systems: their function and interaction with the soil, McGrawHill Book Company (UK) Limited, pp.298

Ryan, R.P., Germaine, K., Franks, A., Ryan, D.J. and Dowling, D.N. 2008. Bacterial endophytes: recent developments and applications, FEMS Microbiol. Lett. 278(1): 1-9.

Singh, R., Singh, S., Parihar, P., Singh, V.P. and Prasad, S.M. 2015. Arsenic contamination, consequences and remediation techniques: a review, Ecotoxicol Environ Saf. 112: 247270.

Smith, J. A. L., Weber, J. and Naidu, R. 2008. Arsenic uptake and speciation in rice plants grown under greenhouse conditions with arsenic contaminated irrigation water, Sci Total Environ. 392 (2-3):277-283.

Sneath, P.H.A., Mair, N.S., Sharpe, M.E., Holt, J.G., Frank, C., Prager, R., Rabsch, W. and Feil, F.B.S. 1986. Bergey's manual of systematic bacteriology ,9th ed., vol. 2. Williams and Wilkins. Baltimore, London. pp: 1599.

Weis, J.S. and Weis, P. 2004. Metal uptake, transport and release by wetland plants: implications for phytoremediation and restoration, Environ Int. 30(5): 685-700.

Weyens, N., Van Der Lelie, D., Taghavi, S. and Vangronsveld, J. 2009. Phytoremediation: plantendophyte partnerships take the challenge, Curr Opin Biotechnol. 20: 248-254.

Zhao, D., Zhao, H., Zhao, D., Zhu, X., Wang, Y., Duan, Y. and Chen, L. 2018. Isolation and identification of bacteria from rhizosphere soil and their effect on plant growth promotion and root-knot nematode disease, Biol. Control. 119: 12-19. 